\title{
Structural Changes in Chamise (Adenostoma fasciculatum) along a Fire-induced Age Gradient
}

\author{
PHILIP W. RUNDEL AND DAVID J. PARSONS
}

\begin{abstract}
Chamise (Adenostoma fasciculatum) undergoes major structural changes in above-ground biomass along a gradient of increasing stand age since fire. Shrub growth in volume and biomass is rapid through 16 years but levels off in older stands. In this early phase of linear biomass increase, net above-ground productivity has a mean of $430 \mathrm{~g} \cdot \mathrm{yr}^{-1}$ for each shrub, or $60 \mathrm{~g} \cdot \mathrm{m}^{-2}$ $\mathrm{yr}^{-1}$ over the period of $2-16$ years stand age. Individual shrubs at 37 years in Sequoia in the southern Sierra Nevada have more than twice the biomass and four times the annual above-ground productivity of chamise of similar age in the San Gabriel Mountains of Los Angeles County. Between 16 and 37 years, shrub senescence increases with no increase in above-ground biomass and a sharp reduction of available photosynthetic surface area. Total stand biomass continues increasing with stand age up to 37 years as shrub biomass increases, with a maximum at approximately $15,000 \mathrm{~kg} \cdot \mathrm{ha}^{-1}$. Fine fuels less than $10 \mathrm{~mm}$ comprise more than $500 \mathrm{~g} \cdot \mathrm{m}^{-2}$ in all chamise canopy ages, providing an important structural element of flammability.
\end{abstract}

The characteristic evergreen shrub or chaparral vegetation of central and southern California is a classic example of a fire-type community (Hanes 1977; Biswell 1974). Occurring in both pure and mixed stands throughout most of the state's foothill zone, chamise (Adenostoma fasciculatum $\mathrm{H}$. \& A.) is the single most common chaparral species (Hanes 1965, 1977). Physical characteristics which are well adapted to rapid rates of energy release (Countryman and Philpot 1970) combine with typical hot and dry summers, volatile ether extractives, and low fuel moistures to make chamise an especially flammable fuel type. Its wide distribution and frequent proximity to developed and urban areas has made chamise the subject of growing management concern as well as scientific investigation (Parsons 1976; Hanes 1977).

Following fire, chamise characteristically resprouts from a root crown as well as germinating from heat-treated seeds (Christensen and Muller 1975). In most cases the sprouts form the basis of a rejuvenated stand which rapidly matures to the point where within about 15 years the fuel loading (weight per unit area) is thought to be able to again support a moderately intense fire (Philpot 1973). During the past century fire

\footnotetext{
Authors are associate professor, Department of Ecology and Evolutionary Biology, University of California, Irvine 92717; and research scientist, Sequoia and Kings Canyon National Parks, Three Rivers, California 93271.

The authors greatly acknowledge the assistance of Gail Baker, Sue MacLeod, and Steve DeBenedetti in carrying out this study. Funding was provided by the National Park Service and by a National Science Foundation Grant.

Manuscript received May 1, 1978.
}

suppression policies have greatly reduced fire frequencies in most chaparral areas. As a result there now exist large areas of overmature chamise chaparral which constitute highly flammable, potentially catastrophic fuel accumulations as well as being of little value as browse of wildlife.

This report provides a detailed analysis of structural changes in chamise following different periods since fire. Such information is of value in understanding the concept of senescence as it applies to shrub growth as well as adaptations of chamise to periodic burning. Analysis of growth patterns,

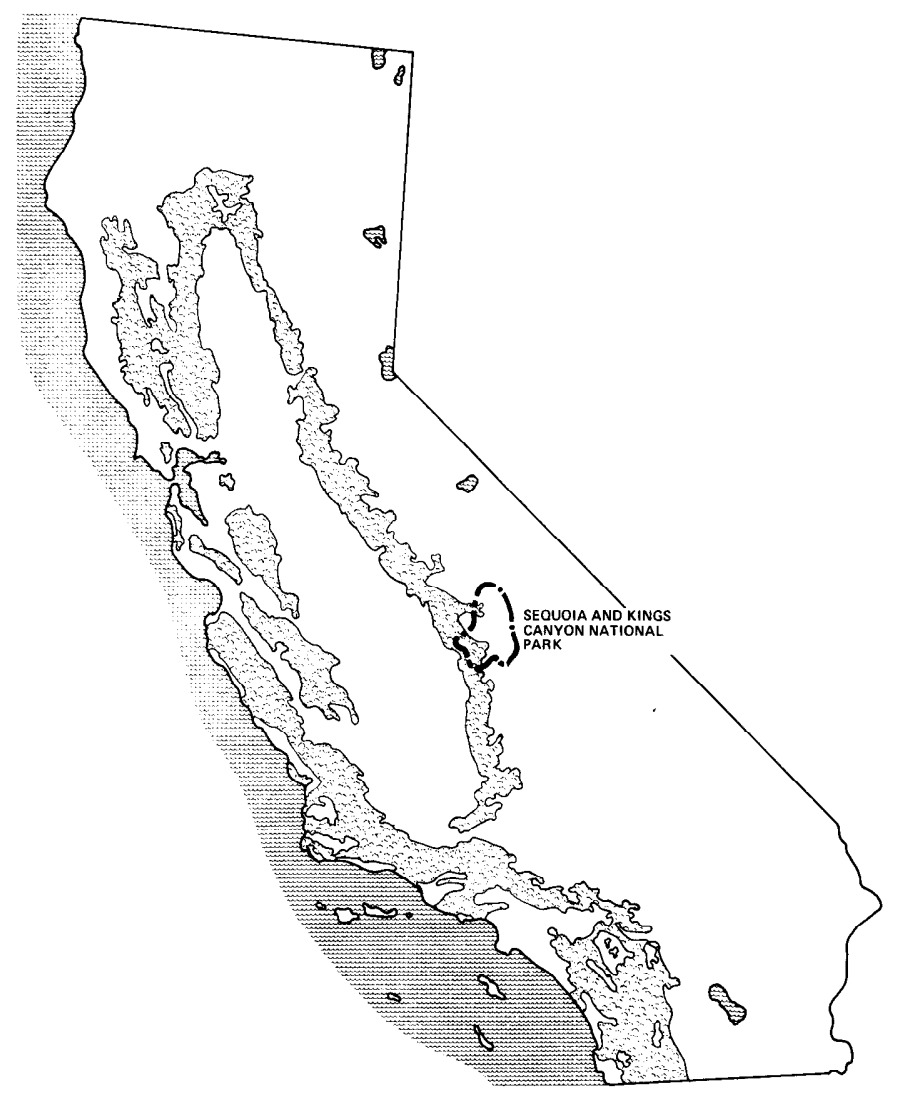

Fig. 1. Location of research area in Sequoia National Park. The Distribution of chaparral vegetation within California is shown by the textured area. Adapted from Bentley (1967). 
productivity and biomass distribution directly relate to potential flammability and thus may eventually provide a key to predicting burning characteristics.

\section{Study Area and Methods}

The study area is located within the low elevation foothills of Sequoia National Park in the southern Sierra Nevada of California (Fig. 1). Past fires in this area have occurred almost exclusively during the dry season (summer or fall) and have been of moderate to high intensity. Specific study sites are located within stands of nearly pure chamise along a fire induced age gradient. The sites, located on southerly exposures of moderate slope between 750 and $900 \mathrm{~m}$ in elevation, have respectively experienced $2,6,16,37$ and something over 60 years since last being burned. Each site is characterized by a predominance of chamise with only the youngest sites showing even a moderate abundance of any other woody species. Previous work at these same sites has documented an increase in woody cover and height as well as litter accumulation with increasing time since fire (Parsons 1976).

The climate of the study area is characterized by an annual precipitation of about $70 \mathrm{~cm}$ which falls mainly as winter rain. The summers are hot and dry with daytime temperatures often exceeding $40^{\circ} \mathrm{C}$. The soils are generally a shallow, sandy loam of granitic origin. Extensive soil sampling throughout the study area shows little variation in soil type (unpublished data).

At each study site three to five typical shrubs were selected for analysis. Since "typical" shrubs were selected for analysis in each stand as the best means of sampling biomass distribution, no attempt has been made to provide statistical interpretation of the data. Shrub dimensions and biomass are quite consistent in the 2-, 6- and 16-year stands, but somewhat variable in the 37- and over 60 -year stands. All above-ground biomass was sampled in $30 \mathrm{~cm}$ canopy height increments. Mean diameter of the shrub at each height increment was recorded. Shrub dimensions were used to calculate biomass data for unit area of canopy cover. Biomass samples were divided into leaves and stems with the latter subdivided into $0-5,5-10,10-20,20-30$, and $30+\mathrm{mm}$ diameter classes.

Oven-dry weights of each fraction were determined in the laboratory, and leaf and stem surface areas calculated following procedures in Countryman and Philpot (1970). For leaves this method calculates leaf surface area on a geometrical model of an individual leaf as a cone and two frustulums. Biomass data include both living and dead stems, but exclude standing dead branches predating the last fire.

\section{Results and Discussion}

Structural characteristics of chamise shrubs along a gradient of stand age since fire show a rapid early growth leveling off beyond 16 years (Table 1). Shrub volumes increase rapidly up through our 16 year stand, but only moderate canopy diameter and height changes occur beyond this age (Fig. 2). Total shrub above-ground biomass (for an individual shrub) increases linearly for 15-20 years with a mean annual increment of 430 $\mathrm{g} \cdot \mathrm{yr}^{-1}$ (Fig. 3). Between our 16 and 37 year stands, the slope of annual growth decreases gradually in a nonlinear manner to a biomass peak of $8,900 \mathrm{~g}$. Overmature stands greater than 60

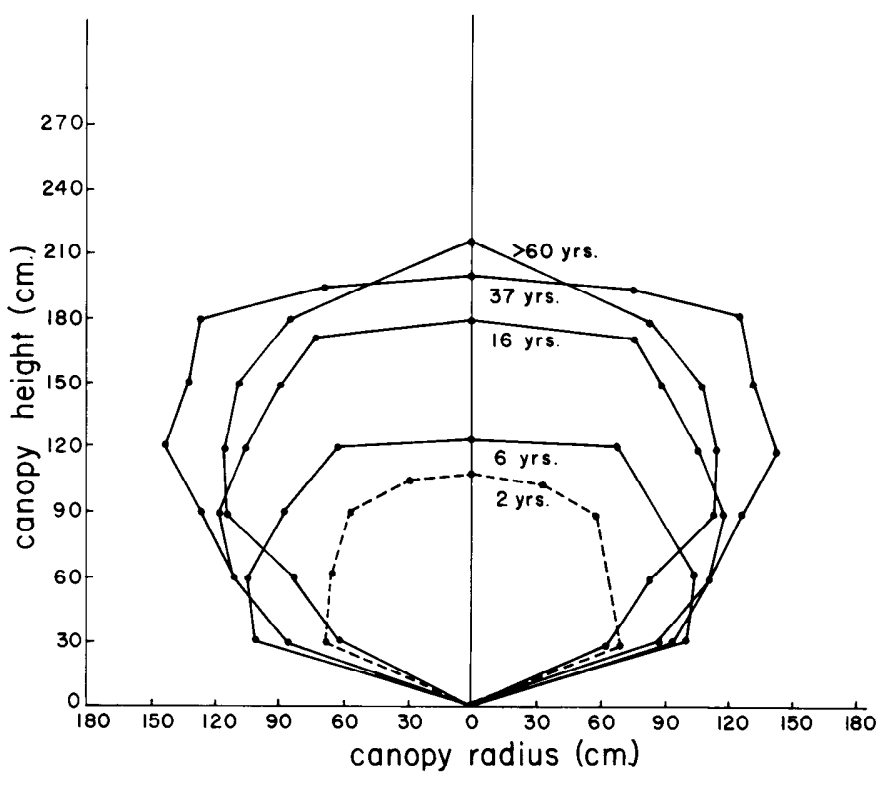

Fig. 2. Cross-section of mean canopy dimensions of Adenostoma fasciculatum along a gradient of stand age since fire.

years in age have a reduced biomass, apparently due to death and breakage of individual branches. On a unit area basis, net annual above-ground productivity approaches linearity from 2 to 16 years, with a slope of approximately $60 \mathrm{~g} \cdot \mathrm{m}^{-2} \mathrm{yr}^{-1}$. From 16 years on, above-ground biomass remains relatively steady at about $1,400 \mathrm{~g} \cdot \mathrm{m}^{-2}$ (Table 1 ).

These data from above-ground biomass of individual shrubs

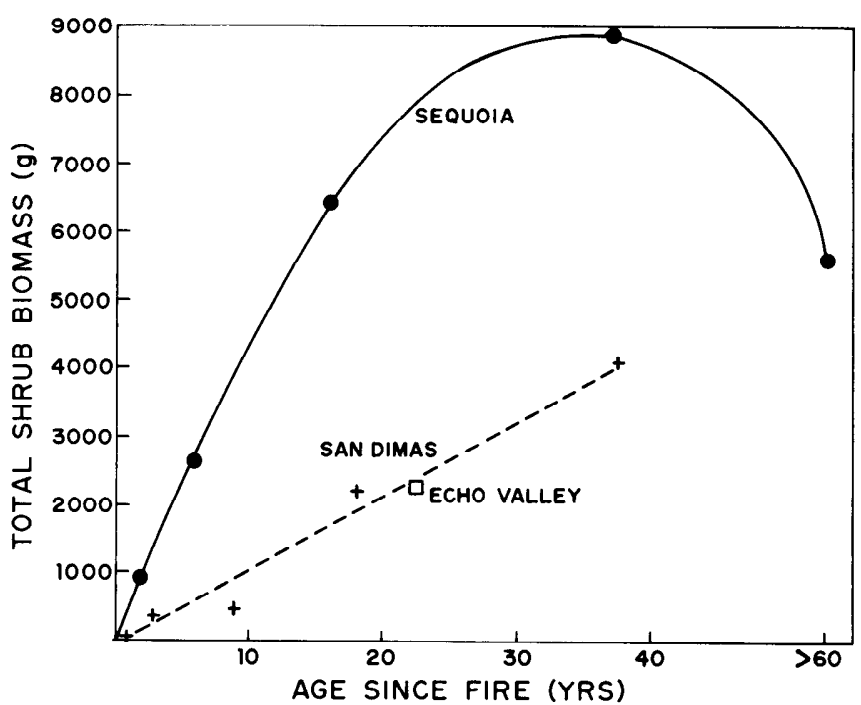

Fig. 3. Above-ground biomass changes of individual Adenostoma fasciculatum along a gradient of stand age since fire for Sequoia National Park, San Dimas, and Echo Valley. San Dimas data adapted from Specht (1969), Echo Valley data from Mooney, et al. (1977).

Table 1. Structural characteristics of Adenostoma fasciculatum shrubs along a gradient of stand age since fire.

\begin{tabular}{|c|c|c|c|c|c|c|c|}
\hline $\begin{array}{l}\text { Age } \\
\text { (yrs) }\end{array}$ & $\begin{array}{c}\text { Above-ground } \\
\text { biomass } \\
\left(\mathrm{g} \cdot \mathrm{m}^{-2}\right)\end{array}$ & $\begin{array}{l}\text { Leaf biomass } \\
\left(\mathrm{g} \cdot \mathrm{m}^{-2}\right)\end{array}$ & $\begin{array}{c}\text { Stem biomass } \\
\left(\mathrm{g} \cdot \mathrm{m}^{-2}\right)\end{array}$ & $\begin{array}{c}\% \text { leaf } \\
\text { biomass }\end{array}$ & $\begin{array}{c}\text { \% stem } \\
\text { biomass }\end{array}$ & $\begin{array}{c}\text { Leaf area } \\
\text { index } \\
\left(\mathrm{m}^{2} \cdot \mathrm{m}^{-2}\right)\end{array}$ & $\begin{array}{l}\text { Stem area index } \\
\qquad\left(\mathrm{m}^{2} \cdot \mathrm{m}^{-2}\right)\end{array}$ \\
\hline 2 & 593 & 232 & 361 & 39.1 & 60.9 & 1.79 & 0.45 \\
\hline 6 & 793 & 200 & 593 & 25.2 & 74.8 & 1.53 & 0.61 \\
\hline 16 & 1486 & 286 & 1200 & 19.2 & 80.8 & 2.20 & 0.84 \\
\hline 37 & 1400 & 159 & 1241 & 11.4 & 88.6 & 1.23 & 0.73 \\
\hline 760 & 1370 & 156 & 1214 & 11.4 & 88.6 & 1.22 & 0.63 \\
\hline
\end{tabular}


and above-ground productivity for our stands at Sequoia National Park are considerably higher than values previously described for chamise in Southern California. At San Dimas in the San Gabriel Mountains, chamise shrubs in a 37 year old stand have a mean biomass of $4,100 \mathrm{~g}$ (Specht 1969), less than half the values in our stands of the same age. Our higher values of above-ground biomass of individual shrubs and productivity hypothetically are related to shortened summer drought periods in the Sierra Nevada resulting from more favorable ground water supplies. Chamise shrubs at San Dimas have a linear growth rate up to this age with a slope of $110 \mathrm{~g} \cdot \mathrm{yr}^{-1}$ (Specht 1969). At Echo Valley in San Diego County, chamise shrubs in a 22-year old stand average $1,726 \mathrm{~g} \cdot \mathrm{m}^{-2}$ with mean shrub dimensions of $1.16 \mathrm{~m}$ in height and $0.98 \mathrm{~m}$ diameter (Mooney et al. 1977). Mean shrub above-ground biomass at Echo Valley is $2,271 \mathrm{~g}$.

While total above-ground biomass of chamise at Sequoia increases steadily in younger stands, the relative composition of leaves and stems in the biomass changes greatly. Leaf biomass per unit area remains high in younger stands, but drops in the two older stands (Table 1). Stem biomass increases rapidly in younger stands, but levels off after 16 years. Leaf biomass drops from $39 \%$ of total above-ground biomass in the two-year old stand to $11 \%$ in the oldest two age classes.

A good indication of relative shrub senescence can be seen in values of leaf area index (LAI) along the stand age gradient. Since chamise typically retains its leaves for only two growing seasons, LAI should be directly related to productivity. Values for LAI reach their highest point of $2.20 \mathrm{~m}^{2} \cdot \mathrm{m}^{-2}$ in the 16 -year old stand, then drop to only 1.23 and $1.22 \mathrm{~m}^{2} \cdot \mathrm{m}^{-2}$ in the oldest two stands (Table 1). This reduced LAI provides strong indirect evidence of morphological senescence in the two oldest stands and highest productivity at our 16-year stand. Since aboveground productivity shows no increase beyond 16 years (Table 1), the hypothetical increase of total productivity around this age may relate to increased root growth.

At Echo Valley in San Diego County, 22-year old chamise has comparable relative biomass of leaves and stems as our plants, with $17 \%$ leaves and $83 \%$ stems (Mooney et al. 1977). LAI for chamise at Echo Valley is high at $3.09 \mathrm{~m}^{2} \cdot \mathrm{m}^{-2}$.

Changing characteristics of gross shrub structure with age in chamise are associated with major changes of structural characteristics in indvidual canopy levels. Data on the distribution of leaf and stem components with $30 \mathrm{~cm}$ height levels in the canopy are presented in Table 2 . In the two year old stand, more than $60 \%$ of the leaf and stem biomass is concentrated below $30 \mathrm{~cm}$ in the canopy with a LAI in this level of 1.09. At the 6-year age the greatest proportion of stem biomass remains in the lowest level, but the highest leaf biomass and LAI occur at $31-60 \mathrm{~cm}$. Little biomass occurs above $90 \mathrm{~cm}$. In the 16-year old stand biomass is well-distributed up to 120 $\mathrm{cm}$. The highest stem biomass values in the canopy still occur below $30 \mathrm{~cm}$, while leaf biomass peaks at $91-120 \mathrm{~cm}$. LAI is relatively high and even from $31-150 \mathrm{~cm}$. Leaf biomass is concentrated from $61-180 \mathrm{~cm}$ in the canopy of the 37-year-old stand. Values of LAI drop considerably at every level up to 150 $\mathrm{cm}$, indicating a general stand senescense rather than a leaf drop limited to lower branches. These dramatic changes in leaf biomass and LAI between the 16 and 37 year stands indicate that leaf loss is not primarily due to shading effects in the canopy.

Table 2. Height distributions of leaf and stem surface area and biomass in the canopies of Adenostoma fasciculatum along a gradient of stand age since fire.

\begin{tabular}{|c|c|c|c|c|c|c|}
\hline $\begin{array}{l}\text { Age } \\
(y r)\end{array}$ & $\begin{array}{l}\text { Height in canopy } \\
\text { (cm) }\end{array}$ & $\begin{array}{l}\text { Leaf area index } \\
\qquad\left(\mathrm{m}^{2} \cdot \mathrm{m}^{-2}\right)\end{array}$ & $\begin{array}{l}\text { Stem area index } \\
\left(\mathrm{m}^{2} \cdot \mathrm{m}^{-2}\right)\end{array}$ & $\begin{array}{l}\text { Leaf biomass } \\
\left(\mathrm{g} \cdot \mathrm{m}^{-2}\right)\end{array}$ & $\begin{array}{l}\text { Stem biomass } \\
\left(\mathrm{g} \cdot \mathrm{m}^{-2}\right)\end{array}$ & $\begin{array}{c}\text { Total above-ground } \\
\text { biomass } \\
\left(\mathrm{g} \cdot \mathrm{m}^{-2}\right)\end{array}$ \\
\hline 2 & $\begin{array}{r}0-30 \\
31-60 \\
61-90 \\
91-120\end{array}$ & $\begin{array}{l}1.09 \\
0.53 \\
0.14 \\
0.03\end{array}$ & $\begin{array}{l}0.29 \\
0.13 \\
0.03 \\
0.004\end{array}$ & $\begin{array}{r}141 \\
69 \\
18 \\
4\end{array}$ & $\begin{array}{r}247 \\
91 \\
20 \\
4\end{array}$ & $\begin{array}{r}388 \\
160 \\
38 \\
8\end{array}$ \\
\hline 6 & $\begin{array}{r}0-30 \\
31-60 \\
61-90 \\
91-120 \\
121-150\end{array}$ & $\begin{array}{l}0.46 \\
0.54 \\
0.38 \\
0.13 \\
0.02\end{array}$ & $\begin{array}{l}0.23 \\
0.23 \\
0.11 \\
0.03 \\
0.01\end{array}$ & $\begin{array}{r}59 \\
71 \\
50 \\
17 \\
3\end{array}$ & $\begin{array}{r}270 \\
202 \\
93 \\
26 \\
2\end{array}$ & $\begin{array}{r}329 \\
273 \\
143 \\
43 \\
5\end{array}$ \\
\hline 16 & $\begin{array}{r}0-30 \\
31-60 \\
61-90 \\
91-120 \\
120-150 \\
151-180\end{array}$ & $\begin{array}{l}0.18 \\
0.49 \\
0.38 \\
0.68 \\
0.40 \\
0.07\end{array}$ & $\begin{array}{l}0.16 \\
0.21 \\
0.15 \\
0.19 \\
0.12 \\
0.01\end{array}$ & $\begin{array}{l}23 \\
64 \\
50 \\
88 \\
52 \\
10\end{array}$ & $\begin{array}{r}352 \\
330 \\
227 \\
203 \\
77 \\
10\end{array}$ & $\begin{array}{r}375 \\
394 \\
227 \\
291 \\
129 \\
20\end{array}$ \\
\hline 37 & $\begin{array}{r}0-30 \\
31-60 \\
61-90 \\
91-120 \\
121-150 \\
151-180 \\
181-210\end{array}$ & $\begin{array}{l}0.02 \\
0.13 \\
0.30 \\
0.26 \\
0.22 \\
0.21 \\
0.09\end{array}$ & $\begin{array}{l}0.09 \\
0.17 \\
0.19 \\
0.12 \\
0.08 \\
0.06 \\
0.02\end{array}$ & $\begin{array}{r}3 \\
17 \\
39 \\
34 \\
29 \\
27 \\
12\end{array}$ & $\begin{array}{r}292 \\
363 \\
281 \\
152 \\
83 \\
51 \\
18\end{array}$ & $\begin{array}{r}295 \\
380 \\
320 \\
186 \\
112 \\
78 \\
30\end{array}$ \\
\hline 60 & $\begin{array}{r}0-30 \\
31-60 \\
61-90 \\
91-120 \\
121-150 \\
151-180 \\
181-210\end{array}$ & $\begin{array}{l}0.02 \\
0.08 \\
0.18 \\
0.37 \\
0.30 \\
0.20 \\
0.06\end{array}$ & $\begin{array}{l}0.10 \\
0.13 \\
0.11 \\
0.14 \\
0.09 \\
0.05 \\
0.01\end{array}$ & $\begin{array}{r}3 \\
10 \\
23 \\
48 \\
38 \\
26 \\
7\end{array}$ & $\begin{array}{c}360 \\
321 \\
201 \\
189 \\
89 \\
43 \\
8\end{array}$ & $\begin{array}{c}363 \\
331 \\
224 \\
237 \\
127 \\
69 \\
15\end{array}$ \\
\hline
\end{tabular}


Table 3. Size class distribution of above-ground biomass of Adenostoma fasciculatum in relation to stand coverage and age since last fire. All values are in $\mathbf{k g} \cdot \mathbf{h a}^{-1}$.

\begin{tabular}{|c|c|c|c|c|c|c|c|c|}
\hline \multicolumn{3}{|c|}{$\%$} & \multicolumn{5}{|c|}{ Stems (diameter class in $\mathrm{mm}$ ) } & \multirow{2}{*}{$\begin{array}{l}\text { Total above- } \\
\text { ground biomass }\end{array}$} \\
\hline Age & coverage & Leaves & $0-5$ & $5-10$ & $10-20$ & $20-30$ & 30 & \\
\hline \multirow[t]{5}{*}{2} & 20 & 464 & 556 & 156 & 11 & & & 1187 \\
\hline & 40 & 928 & 1111 & 313 & 22 & & & 2374 \\
\hline & 60 & 1392 & 1667 & 469 & 33 & & & 3561 \\
\hline & 80 & 1855 & 2222 & 626 & 43 & & & 4746 \\
\hline & 100 & 2319 & 2778 & 783 & 54 & & & 5934 \\
\hline \multirow[t]{5}{*}{6} & 20 & 399 & 642 & 406 & 137 & & & 1584 \\
\hline & 40 & 798 & 1284 & 813 & 274 & & & 3169 \\
\hline & 60 & 1197 & 1926 & 1219 & 411 & & & 4753 \\
\hline & 80 & 1595 & 2569 & 1626 & 548 & & & 6338 \\
\hline & 100 & 1994 & 3211 & 2032 & 685 & & & 7922 \\
\hline \multirow[t]{5}{*}{16} & 20 & 573 & 726 & 469 & 782 & 310 & 112 & 2972 \\
\hline & 40 & 1145 & 1453 & 938 & 1565 & 619 & 224 & 5944 \\
\hline & 60 & 1718 & 2179 & 1407 & 2347 & 929 & 336 & 8917 \\
\hline & 80 & 2290 & 2906 & 1875 & 3130 & 1238 & 449 & 11889 \\
\hline & 100 & 2863 & 3632 & 2344 & 3913 & 1548 & 561 & 14861 \\
\hline \multirow[t]{8}{*}{37} & 20 & 319 & 556 & 435 & 928 & 378 & 184 & 2800 \\
\hline & 40 & 637 & 1113 & 870 & 1856 & 756 & 368 & 5599 \\
\hline & 60 & 956 & 1669 & 1305 & 2784 & 1133 & 552 & 8399 \\
\hline & 80 & 1274 & 2226 & 1739 & 3711 & 1511 & 736 & 11198 \\
\hline & 100 & 1593 & 2783 & 2174 & 4639 & 1889 & 920 & 13998 \\
\hline & 120 & 1912 & 3339 & 2609 & 5567 & 2267 & 1104 & 16798 \\
\hline & 140 & 2230 & 3896 & 3044 & 6495 & 2645 & 1288 & 19597 \\
\hline & 160 & 2548 & 4452 & 3479 & 7423 & 3022 & 1472 & 22397 \\
\hline \multirow[t]{8}{*}{60} & 20 & 313 & 420 & 288 & 1009 & 516 & 196 & 2742 \\
\hline & 40 & 626 & 839 & 575 & 2017 & 1031 & 393 & 5481 \\
\hline & 60 & 939 & 1259 & 863 & 3026 & 1547 & 589 & 8223 \\
\hline & 80 & 1252 & 1678 & 1150 & 4034 & 2062 & 786 & 10962 \\
\hline & 100 & 1565 & 2098 & 1437 & 5042 & 2578 & 982 & 13702 \\
\hline & 120 & 1878 & 2518 & 1725 & 6051 & 3094 & 1178 & 16444 \\
\hline & 140 & 2191 & 2937 & 2012 & 7059 & 3609 & 1375 & 19183 \\
\hline & 160 & 2504 & 3357 & 2300 & 8068 & 4125 & 1571 & 21925 \\
\hline
\end{tabular}

Instead, some physiological senescence with age may be responsible for the observed morphological changes.

On a stand basis the amount of chamise biomass can be calculated from our data for a range of values for canopy coverage (Table 3 ). While individual shrub biomass and canopy size increase with age, stand coverage concurrently increases. Parsons (1976) described vegetation structure of the four oldest stands described here, with total ground cover of chamise increasing steadily in a progression of $17,74,130$, and $150 \%$ in these stands. Values above $100 \%$ result from overlap of canopies in the oldest stands. Calculating from our data for the same stands two years later, total chamise biomass would be $1,347 \mathrm{~kg} \cdot \mathrm{hg}^{-1}$ at 6 years, $10,997 \mathrm{~kg} \cdot \mathrm{ha}^{-1}$ at 16 years, 19,317 $\mathrm{kg} \cdot \mathrm{ha}^{-1}$ at 37 years, and $20,553 \mathrm{~kg} \cdot \mathrm{ha}^{-1}$ at over 60 years. Interpolating from Table 3 should allow estimation of biomass accumulation in other stands under similar growing conditions where stand age and chamise coverage are known.

Size class distribution of fuels is an important structural component of flammability. In chaparral fires where branches greater than $10 \mathrm{~mm}$ are seldom consumed, the high percentage of fine branch material in chamise adds considerably to its flammable characteristics. The relative biomass of individual size class components of chamise shown in Figure 4 demonstrates this pattern. Through 16 years more than half of the total shrub biomass is comprised of fine leaves and stems less than $10 \mathrm{~mm}$ diameter.

Even at greater ages, the relative amount of these fine size classes is much higher than comparable values for other chaparral shrub species (Rundel unpublished data). On a unit area basis, the biomass of fine fuel sizes remains high in all stand size classes. Leaf biomass and stem biomass at both the $0-5 \mathrm{~mm}$ and $5-10 \mathrm{~mm}$ size classes peaks at 16 years for our sample points with a total of $830 \mathrm{~g} \cdot \mathrm{m}^{-2}$ (Fig. 5), but the total of

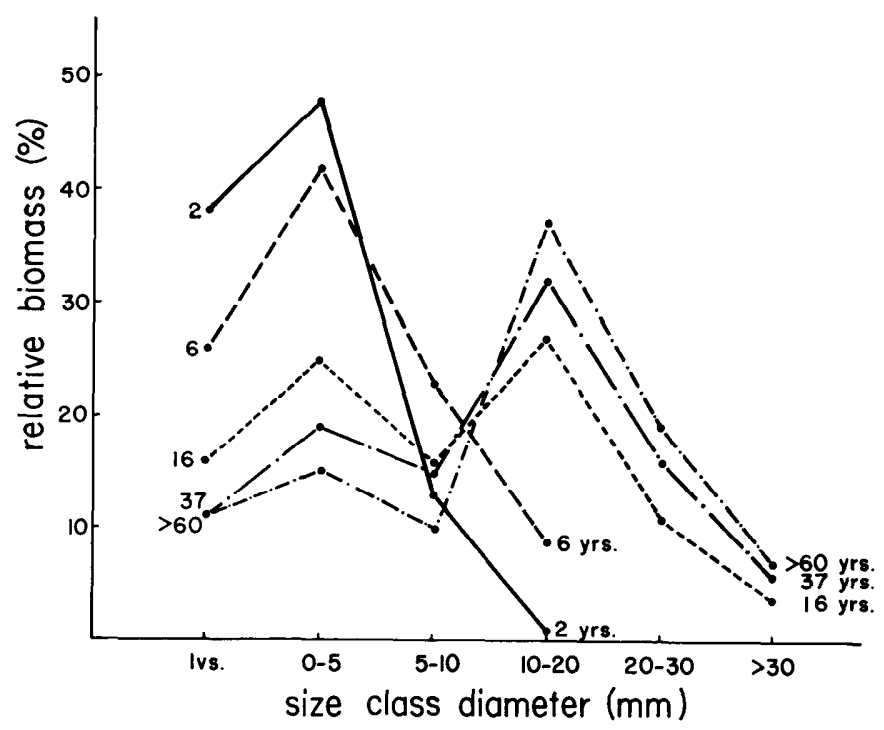

Fig. 4. Relative biomass of shrub canopies of Adenostoma fasciculatum in relation to size class diameter of stem biomass. Data are shown for five stand ages. 


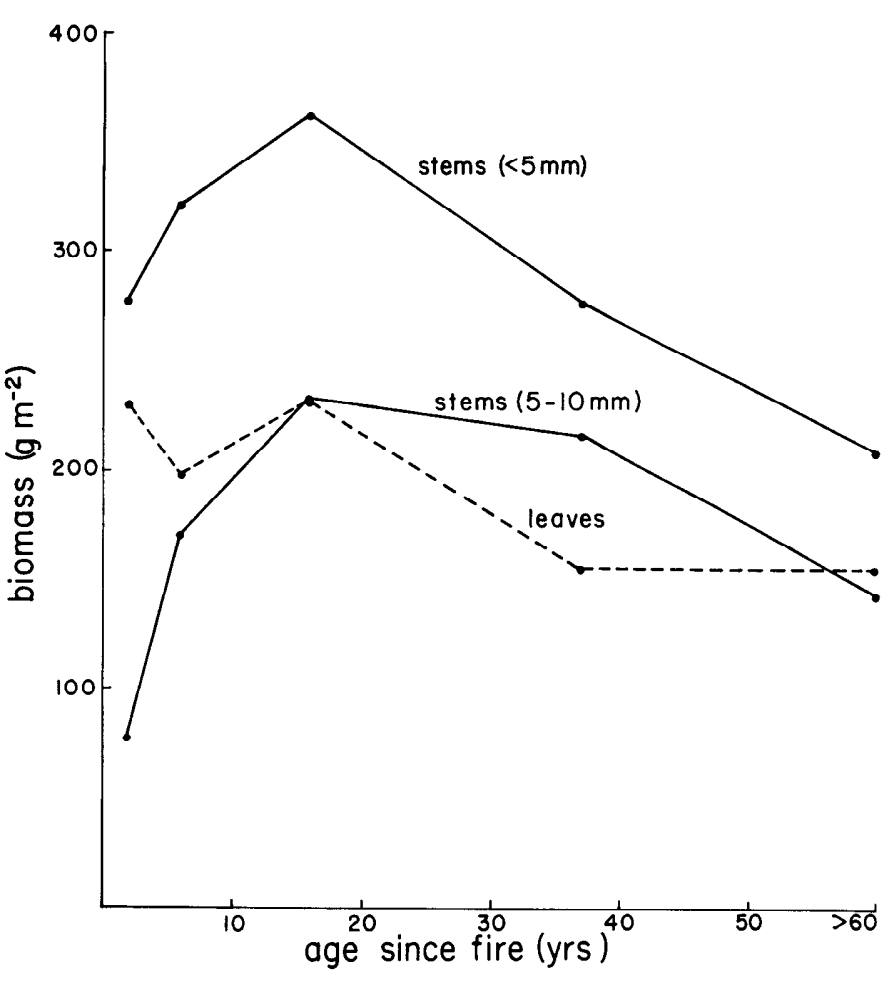

Fig. 5. Biomass $\left(\mathrm{g} \cdot \mathrm{m}^{-2}\right)$ of leaves, stems $0-5 \mathrm{~mm}$, and stems $5-10 \mathrm{~mm}$ of Adenostoma fasciculatum along a gradient of stand age since fire.

fine fuel biomass exceeds $500 \mathrm{~g} \cdot \mathrm{m}^{-2}$ at all ages. This indicates high potential flammability at all age classes. This factor combined with the increased total biomass and increased percentage of dead woody material within the shrub canopy for the older age classes (Parsons 1976) are important structural bases for the high fire danger commonly attributed to stands of mature chamise.

\section{Conclusions}

Too few data are currently available assessing fuel loading and fuel structural characteristics of the highly flammable chaparral areas of California. Such information is of critical importance, however, in providing land managers and fire control specialists with a basis for predicting potential flammability for natural stands of vegetation. Increasing interest in the reduction of fire hazards in chaparral areas through prescribed burning will require more data of this type to provide effective fire modelling (see Rothermel and Philpot 1973) and fire management.

The data presented here indicate that change in flammability resulting from increased stand age may result not only from increased above-ground biomass, but from alterations in the fuel size distribution as well. Structural comparisons of chamise from Sequoia National Park and from Southern California clearly indicate that considerable geographic variation in structure and productivity does occur within California. While the data presented here may be site specific to the southern Sierra Nevada, the methods used and concepts discussed are applicable to many other brushland communities. Additional empirical data on relative flammability of fuels and rates of fire spread will be required in the future to refine fire management programs to the desirable state of predictive accuracy.

\section{Literature Cited}

Bentley, J.R. 1967. Conversion of chaparral areas to grassland: techniques used in California. Agr. Handb. No. 328. U.S. Dep. Agr.

Biswell, H.H. 1974. Effects of fire on chaparral. In. Fire and Ecosystems. Edited by T.T. Kozlowski and C.E. Ahlgren. Academic Press, New York, p. 321-364.

Christensen, N.L., and C.H. Muller. 1975. Effects of fire on factors controlling plant growth in Adenostoma chaparral. Ecol. Monogr. 45: 29-55.

Countryman, C.M., and C.W. Philpot. 1970. Physical characteristics of chamise as a wildland fuel. Pacific SW Forest and Range Exp. Sta. Res. Pap. PSW-66. Berkeley, Calif. 16p.

Hanes, T.L. 1965. Ecological studies on two closely related chaparral shrubs in Southern California. Ecol. Monogr. 35: 213-235.

Hanes, T.L. 1977. Chaparral. In: Terrestrial Vegetation of California. Edited by M.G. Barbour and J. Major. Wiley \& Sons, New York p. 417-470.

Mooney, H.A., J. Kummerow, A.W. Johnson, D.J. Parsons, S. Keeley, A. Hoffmann, R.I. Hays, J. Gilberto, and C. Chu. 1977. The producerstheir resources and adaptive responses. In: Convergent Evolution in Chile and California. Edited by H.A. Mooney. Dowden, Hutchinson and Ross, Stroudsburg, Penn., p 85-143.

Parsons, D.J. 1976. The role of fire in natural communities: an example from the southern Sierra Nevada, California. Environ. Conserv. 3: 91-99.

Philpot, C.W. 1974. The changing role of fire on chaparral lands. In: Symposium on Living with the Chaparral. Edited by M. Rosenthal. Sierra Club, San Francisco, p 131-150.

Rothermel, R.C., and C.W. Philpot. 1973. Fire in wildland management: predicting changes in chaparral flammability. J. Forestry 71: 164-169.

Specht, R.L. 1969. A comparison of the sclerophyllous vegetation characteristic of mediterranean climates in France, California, and Southern Australia. II. Dry matter, energy, and nutrient accumulation. Aust. J. Bot. 17: 293-308. 